\title{
The therapeutic use of magnesium in anesthesiology, intensive care and emergency medicine: a review
}

\author{
[L'usage thérapeutique du magnésium en anesthésiologie, réanimation et \\ médecine d'urgence]
}

Laurent Dubé MD, Jean-Claude Granry MD PhD

Purpose: To review current knowledge concerning the use of magnesium in anesthesiology, intensive care and emergency medicine.

Methods: References were obtained from Medline ${ }^{\circledR}$ (1995 to 2002). All categories of articles (clinical trials, reviews, or metaanalyses) on this topic were selected. The key words used were magnesium, anesthesia, analgesia, emergency medicine, intensive care, surgery, physiology, pharmacology, eclampsia, pheochromocytoma, asthma, and acute myocardial infarction.

Principal findings: Hypomagnesemia is frequent postoperatively and in the intensive care and needs to be detected and corrected to prevent increased morbidity and mortality. Magnesium reduces catecholamine release and thus allows better control of adrenergic response during intubation or pheochromocytoma surgery. It also decreases the frequency of postoperative rhythm disorders in cardiac surgery as well as convulsive seizures in preeclampsia and their recurrence in eclampsia. The use of adjuvant magnesium during perioperative analgesia may be beneficial for its antagonist effects on $\mathrm{N}$-methyl-D-aspartate receptors. The precise role of magnesium in the treatment of asthmatic attacks and myocardial infarction in emergency conditions needs to be determined.

Conclusions: Magnesium has many known indications in anesthesiology and intensive care, and others have been suggested by recent publications. Because of its interactions with drugs used in anesthesia, anesthesiologists and intensive care specialists need to have a clear understanding of the role of this important cation.

Objectif : Mise au point sur les indications du magnésium en anesthésie, en réanimation ou en service d'urgence.

Méthode : Réalisation d'une revue de la littérature récente (1995 à 2002) concernant le magnésium, par le système Medline. Les articles, type étude clinique prospective, revue ou méta-analyses ont été recherchés. Les mots clés utilisés étaient : "magnesium, anesthesia, analgesia, emergency medicine, intensive care, surgery, physiology, pharmacology, eclampsia, pheochromocytoma, asthma, et acute myocardial infarction".

Principaux résultats : Les hypomagnésémies sont fréquentes en postopératoire et en réanimation. Elles sont responsables d'une augmentation de la morbidité et de la mortalité et devraient être détectées et corrigées. Le magnésium diminue la libération des catécholamines, il permet ainsi un meilleur contrôle de la réponse adrénergique lors de l'intubation ou au cours de la chirurgie du phéochromocytome. En chirurgie cardiaque, il diminue la fréquence de survenue des troubles du rythme postopératoires. II diminue la survenue des crises convulsives chez les femmes ayant une pré-éclampsie et diminue les récidives convulsives chez les femmes ayant une éclampsie. II possède des effets antagonistes des récepteurs $N$ methyl-D-aspartate et on pourrait assister à un développement de ses indications en tant qu'adjuvant dans l'analgésie périopératoire. En urgence, sa place dans le traitement de la crise d'asthme et de l'infarctus du myocarde mérite d'être précisée.

Conclusion : Cet ion important de l'organisme a de nombreuses indications reconnues en anesthésie réanimation et de nouvelles indications pourraient apparaître au vue de publications récentes. Ces interactions avec les drogues utilisées en anesthésie en font une molécule importante à connaître des anesthésistes-réanimateurs.

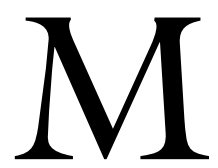

AGNESIUM $(\mathrm{Mg})$ is the fourth most common mineral salt in the human organism and second among intracellular cations. It has calcium antagonist effects, is involved in the regulation of different ion channels and phosphorylation reactions, and serves as a cofactor in many enzymatic systems. Dysmagnesemia,

From the Department of Anesthesiology, University Hospital, Angers, France.

Address correspondence to: Dr. Laurent Dubé, Département d'Anesthésie Réanimation, CHU Angers, 4, rue Larrey, 49033 Angers

Cédex 1, France. Phone: 332413536 35; Fax: 332413539 67; E-mail: Ladube@chu-angers.fr

Accepted for publication December 23, 2002.

Revision accepted March 19, 2003. 
particularly hypomagnesemia, is frequent perioperatively and in intensive care and causes considerable morbidity. Different serum Mg concentrations and dosages will be used, depending on whether they are intended to correct a deficit or for pharmacological purposes. $\mathrm{Mg}$ is used in different surgical situations, obstetrics and perioperative analgesia and has various interactions with the drugs used in anesthesia. In emergency departments, it is being studied in the treatment of myocardial infarction and asthmatic attacks. This review considers Mg physiology and the implications of dysmagnesemia for anesthetic practice. Recent studies of known indications or promising developments of $\mathrm{Mg}$ therapy in anesthesiology, intensive care and emergency medicine are reviewed and discussed.

\section{Mg physiology}

$\mathrm{Mg}$ in the organism

$\mathrm{Mg}$ is a bivalent ion, like calcium, with an atomic weight of 24.312. The human body contains 1 mole $(24 \mathrm{~g}$ of $\mathrm{Mg}$ ). It is the fourth most common mineral salt in the organism after phosphorus, calcium and potassium, ${ }^{1-3}$ the second intracellular cation after potassium, and the fourth plasma cation after sodium, potassium and calcium. ${ }^{4}$ It is concentrated mainly in bone $(60 \%)$, muscle $(20 \%)$ and soft tissues $(20 \%)$. Only a fourth of the Mg contained in bone and muscle is exchangeable. ${ }^{2}$ Extracellular $\mathrm{Mg}$ represents only $1 \%$ of the total. In serum, $\mathrm{Mg}$ is divided into three fractions: ionized (active form), protein-bound and that contained in anion complexes (phosphates and citrates). These three fractions account respectively for 65,27 and $8 \%$ of serum content. Three-fourths of plasma $\mathrm{Mg}$ is ultrafiltrable. ${ }^{2,4}$

The daily recommended $\mathrm{Mg}$ requirement is 250 to $350 \mathrm{mg}(10.4-14.6 \mathrm{mmol})$ in adults ${ }^{4,5}$ and an additional 100 to $150 \mathrm{mg}$ in children and pregnant or nursing women. ${ }^{2}$ Food input is ensured essentially by cocoa powder, chocolate, almonds, peanuts, walnuts, vegetables, cereals and seafood. From 30 to $50 \%$ of ingested $\mathrm{Mg}$ is absorbed $\left(5 \mathrm{mmol} \cdot \mathrm{day}^{-1}\right)$ in decreasing quantity from the small intestine to the colon. Fibres, phytates and oxalic acid appear to reduce $\mathrm{Mg}$ absorption moderately through the formation of a complex that cannot be easily dissociated. The binding of $\mathrm{Mg}$ to anions (phosphates) or fatty acids reduces the quantity of absorbable $\mathrm{Mg}$. The fraction of absorbed $\mathrm{Mg}$ decreases as the quantity ingested increases. ${ }^{2} \mathrm{Mg}$ depletion corresponds to obligatory and uncontrollable digestive losses (around 60\% of ingested $\mathrm{Mg}$ ) and variable losses through renal excretion. Digestive losses are increased by diarrhea or biliary fistula. Urinary excretion of $\mathrm{Mg}$ is normally $5 \mathrm{mmol} \cdot$ day $^{-1}$, but can be reduced to $0.5 \mathrm{mmol} \cdot \mathrm{day}^{-1}$ in the event of severe deficiency. The level is regulated by variations in renal reabsorption, as a function of magnesemia, relative to inputs and bone mobilization. ${ }^{2}$ Around $75 \%$ of plasma $\mathrm{Mg}$ is filtered at the glomerular level. Only $5 \%$ of filtered $\mathrm{Mg}$ is excreted, with reabsorption of 15 to $25 \%$ in the proximal convoluted tubule and 50 to $60 \%$ in the ascending limb of Henle's loop. Diuretics, thiazides, cisplatin, gentamicin and cyclosporine inhibit renal reabsorption. ${ }^{3,5}$

$\mathrm{Mg}$ is mainly intracellular, existing largely $(90 \%)$ in bound form in adenosine triphosphate (ATP) molecules of the cytoskeleton (nucleus, mitochondria and reticulum), in nucleotides, or in enzyme complexes. A small portion of intracellular $\mathrm{Mg}$ (5-14\%, depending on the cells) is found in ionized free form within the cell. Heart muscle cells have a high concentration of total $\mathrm{Mg}$ (1 1-17 $\mathrm{mmol} \cdot \mathrm{L}^{-1}$ of intracellular water). ${ }^{2,6}$

Knowledge about the hormonal regulation of $\mathrm{Mg}$ homeostasis is incomplete. Several hormones are involved in the regulation of $\mathrm{Mg}$ metabolism, namely parathyroid hormone $(\mathrm{PTH})$, calcitonin, vitamin $\mathrm{D}$, insulin, glucagon, epinephrine, antidiuretic hormone, aldosterone and sex hormones. PTH and vitamin D increase intestinal absorption, PTH favours renal reabsorption of $\mathrm{Mg}$ and facilitates its bone reuptake, insulin increases cellular uptake of $\mathrm{Mg}$, and glucagon is conducive to its renal reabsorption. 7,8

\section{Biological considerations}

Assay of total plasma $\mathrm{Mg}$ by spectrophotometry is precise and easy to perform $\left(0.7-1.1 \mathrm{mmol} \cdot \mathrm{L}^{-1}\right.$ or $1.4-2.2$ $\mathrm{mEq} \cdot \mathrm{L}^{-1}$, or $\left.16.8-26.4 \mathrm{mg} \cdot \mathrm{L}^{-1}\right)$. However, owing to the intracellular nature of this ion, these values are not exactly indicative of the $\mathrm{Mg}$ pool in the organism or of a possible state of deficiency. ${ }^{4}$ Other concentrations have been studied to allow better assessment of true $\mathrm{Mg}$ deficiencies, namely intracellular $\left(8-10 \mathrm{mmol} \cdot \mathrm{L}^{-1}\right)^{6}$ and ionized plasma $\mathrm{Mg}\left(0.65 \pm 0.1 \mathrm{mmol} \cdot \mathrm{L}^{-1}\right)$ concentrations. Interferences with calcium ions at the level of the $\mathrm{Mg}$ electrode reduce the relevance of the ionized $\mathrm{Mg}$ assay. ${ }^{4}$ Because of the long life of $\mathrm{Mg}$ and its slow turnover, erythrocytic $\mathrm{Mg}$ might be a better indicator of deficiency (values in the literature: $2.10 \pm 0.4$ mmol. $\left.\mathrm{L}^{-1}\right)^{1,3}$ Lymphocytic $\mathrm{Mg}$ would appear to be a better indicator of the $\mathrm{Mg}$ content of muscle and myocardium and of ionized Mg. ${ }^{1}$ However, the relation between these last evaluations and the $\mathrm{Mg}$ pool of the organism remains uncertain. ${ }^{4}$

Urinary excretion of $\mathrm{Mg}$ is highly variable, ranging from $5 \mathrm{mmol} \cdot \mathrm{day}^{-1}$ in the normomagnesimic subject to $0.5 \mathrm{mmol} \cdot \mathrm{day}^{-1}$ in the deficient subject. Measurement of urinary excretion helps separate renal 
from non-renal causes of hypomagnesemia. In the presence of hypomagnesemia, high urinary excretion suggests that increased renal loss is the mechanism of $\mathrm{Mg}$ depletion, whereas low urinary excretion suggests miscellaneous or gastrointestinal causes. Studies of the urinary excretion of $\mathrm{Mg}$ after a loading test can help diagnose $\mathrm{Mg}$ deficiency when magnesemia is normal: the subject without deficiency excretes more than $60-70 \%$ of $\mathrm{Mg}$ input, whereas the subject with a deficiency excretes less than $50 \%{ }^{9,10}$

Various changes in $\mathrm{Mg}$ can occur during the perioperative period. Plasma concentrations are decreased after abdominal ${ }^{11,12}$ or orthopedic surgery. ${ }^{13}$ After heart surgery, mean magnesemia is reduced, ${ }^{14,15}$ and the frequency of hypomagnesemia increased from $19.2 \%$ preoperatively to $71 \%$ immediately after surgery before dropping slightly to $65.6 \% 24 \mathrm{hr}$ later. ${ }^{16}$ For Zuccala et al., the depletion of intracellular Mg would appear to be closely correlated with reduced serum concentrations. These authors found that both concentrations decreased after orthopedic surgery. ${ }^{17}$

\section{Cellular physiological properties of $\mathrm{Mg}$}

ACTION ON MEMBRANE AND MEMBRANE PUMPS

$\mathrm{Mg}$ intervenes in the activation of membrane $\mathrm{Ca}$ ATPase and Na-K ATPase involved in transmembrane ion exchanges during depolarization and repolarization phases. $\mathrm{Mg}$ deficiency impairs the action of ATPase pumps and leads to a reduction of intracellular ATP as well as to increased concentrations of sodium and calcium and decreased concentrations of potassium within the cell. ${ }^{5}$ It would thus appear to act as a stabilizer of cell membrane and intracytoplasmic organelles. ${ }^{18}$

\section{ACTION ON ION CHANNELS}

$\mathrm{Mg}$ is considered to act as a regulator of different ion channels. A low intracellular Mg concentration allows potassium to leave the cell, thereby altering conduction and cellular metabolism. ${ }^{5,18} \mathrm{Mg}$ also exerts its effects on calcium channels of potential-dependent $\mathrm{L}$ type in membrane and on those of sarcoplasmic reticulum. A competitive antagonist action is directed against calcium inflows. By inhibiting the calcium activation dependent on the sarcoplasmic channel, $\mathrm{Mg}$ limits the outflow of calcium from the sarcoplasmic reticulum, the main site of intracellular calcium storage. ${ }^{18}$ Thus, $\mathrm{Mg}$ is a calcium channel blocker and a modulator of calcium channel activity, which means that a rise in intracellular calcium occurs during hypomagnesemia. ${ }^{2,5}$
ENZYMATIC ACTIVATION

Intracellular free $\mathrm{Mg}$ is involved in the energy reactions of phosphorylation and is necessary for the activation of hundreds of enzymatic reactions concerning ATP. ${ }^{18}$ Inorganic phosphate and ATP within the cell reduce free $\mathrm{Mg}$, whereas the conversion of ATP to adenosine diphosphate (ADP) increases it. ${ }^{3}$ In fact, $\mathrm{Mg}$ interacts with the outer two phosphate groups of ATP to form the enzymatic substrate. Intracellular Mg deficiency is correlated with the impaired function of many enzymes utilizing high-energy phosphate bonds, as in the case of glucose metabolism. ${ }^{2}$

\section{Clinical effects of $\mathrm{Mg}$}

CARDIOVASCULAR EFFECTS

The action of $\mathrm{Mg}$ on calcium channels and pumps actually serves as a regulator of transmembrane and intracellular flows. In addition, $\mathrm{Mg}$ has an indirect effect on cardiac muscle cells by inhibiting calcium uptake on the troponin $\mathrm{C}$ of myocytes and thereby influencing myocardial contractility. In a preparation of isolated animal heart, $\mathrm{Mg}$, because of its anticalcium properties, caused a dose-dependent negative inotropic effect. ${ }^{19}$ Rasmussen et al. observed a moderate positive inotropic effect after infusion of $\mathrm{Mg}$ into healthy volunteers, ${ }^{20}$ which could have been related to the vascular effect of $\mathrm{Mg}$ in reducing systemic arteri$\mathrm{al}^{20}$ and pulmonary artery pressures through a decrease of vascular resistance. ${ }^{18}$ In in vitro studies on isolated aorta, the absence of $\mathrm{Mg}$ potentiated the vasoconstrictive effect of angiotensin and acetylcholine, and hypermagnesemia induced the relaxation of smooth muscle. ${ }^{21}$ The role of $\mathrm{Mg}$ in transmembrane movements of calcium and the activation of the adenylate cyclase involved in the synthesis of cyclic adenosine monophosphate (AMP; a vasodilator) could account in part for this effect. A reduction of cyclic AMP in hypomagnesemia induced an increase of vascular tone. ${ }^{22} \mathrm{Mg}$ deficiency may also play a role in the pathogenesis of variant angina or coronary spasm, ${ }^{23}$ and infusion of $\mathrm{Mg}$ can produce coronary dilatation and suppress acetylcholine-induced coronary spasm in patients with vasospastic angina. ${ }^{24}$

In anesthetized dogs, a dose-dependent decrease in heart rate and systolic and diastolic arterial pressures was observed after the infusion of $\mathrm{Mg} .{ }^{25}$ In humans, hemodynamic studies have shown a peripheral (predominantly arteriolar) vasodilator effect. ${ }^{26,27}$ After the rapid infusion of a dose of 3 or $4 \mathrm{~g}$ of sulfate $\left(\mathrm{MgSO}_{4}\right)$, a reduction of systolic arterial pressure occurred, in relation to decreased systemic vascular resistance. Positive inotropic and chronotropic effects compensated for the former by increasing the heart 
index, whereas pulmonary vascular resistance remained unchanged. In the study by Vigorito et al., coronary vascular resistance decreased as coronary blood flow increased. ${ }^{26}$

Disturbances in cellular ionic movements induced by dysmagnesemia could affect the excitability of the heart cells of nodal tissue responsible for cardiac rhythm disorders. ${ }^{18}$ In electrocardiographic studies in anesthetized dogs, a dose-dependent lengthening of the PR and RR intervals was noted, as well as a dosedependent increase of QRS duration, without any modification of the QTc interval. A dose-dependent lengthening of atrioventricular conduction time was also observed. ${ }^{25}$

\section{MUSCLE AND NEUROMUSCULAR TRANSMISSION} Calcium and $\mathrm{Mg}$ have opposite effects on muscle. Hypomagnesemia stimulates contraction, whereas hypocalcemia induces relaxation. Hypomagnesemia causes rapid, passive release of calcium by the sarcoplasmic reticulum as a result of the opening of calcium channels, whereas high concentrations of $\mathrm{Mg}$ block this process. ${ }^{28}$ Neuromuscular transmission is altered by a preponderant presynaptic effect as well as a postsynaptic effect. Mg acts competitively in blocking the entry of calcium into presynaptic endings. Presynaptic release of acetylcholine is reduced by high $\mathrm{Mg}$ concentrations, thereby altering neuromuscular transmission. ${ }^{4,28} \mathrm{Mg}$ decreases the effects of acetylcholine on postsynaptic muscle receptors and has been shown to increase the threshold of axonal excitation. Hypomagnesemia induces neuromuscular hyperexcitability, ${ }^{3}$ while hypermagnesemia causes neuromuscular weakness as well as a reduction or even an abolition of deep tendon reflexes. Excess serum $\mathrm{Mg}$ concentrations produce progressive inhibition of catecholamine release from adrenergic nerve endings, adrenal medulla and adrenergic postganglionic sympathetic fibres. ${ }^{28,29}$

\section{CENTRAL NERVOUS SYSTEM}

The property of $\mathrm{Mg}$ as an antagonist of $\mathrm{N}$-methyl-Daspartate (NMDA) receptors is the basis for studies of its adjuvant effect in perioperative analgesia. This calcium inhibitory effect causes central arteriolar vasodilation and acts against vasospasm. The inhibition of NMDA receptors and the increased production of vasodilator prostaglandins induced by $\mathrm{Mg}$ could account for the anticonvulsant action of $\mathrm{Mg}$.

\section{OTHER CLINICAL EFFECTS}

The postulated mechanisms for the bronchodilator effects of $\mathrm{Mg}$ include inhibitory action on smooth muscle contraction, histamine release from mast cells and acetylcholine release from cholinergic nerve terminals.,30 The precise mechanism of action for the tocolytic effects ${ }^{31,32}$ of $\mathrm{Mg}$ sulfate is not clearly defined, but may be related to the action of $\mathrm{Mg}$ as a calcium blocker in inhibiting muscle contractions.

\section{Posology and administration of $\mathrm{Mg}$}

$\mathrm{Mg}$ can be administered orally or intravenously. Intramuscular injection is also possible but painful. Oral administration of a daily dose of more than 50 mmol can cause vomiting and diarrhea. In anesthesia and intensive care, the preferred administration route is $i v$. Two injectable forms of $\mathrm{Mg}$ are available, namely $\mathrm{Mg}$ chloride and sulfate. Ten millilitres of a $10 \% \mathrm{Mg}$ chloride $\left(\mathrm{MgCl}_{2}\right)$ solution provide $1 \mathrm{~g}$ of $\mathrm{Mg}$ salts (= $118 \mathrm{mg} \mathrm{Mg}=9 \mathrm{mEq}=4.5 \mathrm{mmol})$, and $10 \mathrm{~mL}$ of a $10 \% \mathrm{Mg}$ sulfate $\left(\mathrm{MgSO}_{4}\right)$ solution provide $\mathrm{lg}$ of $\mathrm{Mg}$ salts $\left(=98 \mathrm{mg} \mathrm{Mg}=8.12 \mathrm{mEq}=4.06 \mathrm{mmol}\right.$ ). ${ }^{5,9}$

Posology differs according to indications, and several dosage recommendations have been proposed. When $\mathrm{Mg}$ sulfate is used to correct a $\mathrm{Mg}$ deficit, the objective is to restore normal serum concentrations, in which case slow infusion of up to $10 \mathrm{~g} \cdot \mathrm{day}^{-1}$ is appropriate. When $\mathrm{Mg}$ is used for its pharmacological properties, more rapid infusion is often necessary to obtain the high plasma concentrations desired. The recommended procedure is rapid infusion of 1 to $2 \mathrm{~g}$ of $\mathrm{MgSO}_{4}$ iv over a ten-minute period followed by continuous $i v$ infusion of 0.5 to $1 \mathrm{~g} \cdot \mathrm{hr}^{-1}$ (reduced to $0.25 \mathrm{~g} \cdot \mathrm{hr}^{-1}$ for patients with renal insufficiency). Administration is performed under continuous electrocardiographic control, and serum concentrations of $\mathrm{Mg}$ or ionized $\mathrm{Mg}$ are determined every six hours. ${ }^{5,9}$ If $\mathrm{Mg}$ is given too quickly, flushing can occur, and bradycardia, cardiac arrhythmia, or cardiac arrest have been reported. ${ }^{33-35}$ There is also the increased risk of the toxic effects of $\mathrm{Mg}$ resulting in renal impairment. ${ }^{35}$

When $\mathrm{Mg}$ was used for tocolysis, adverse effects (flushing and headache) were more frequent with high $\left(5 \mathrm{~g} \cdot \mathrm{hr}^{-1}\right)$ than with low doses $\left(2 \mathrm{~g} \cdot \mathrm{hr}^{-1}\right)$, and pulmonary edema occurred in two patients in the highdose group $v s$ none in the low-dose group. ${ }^{32}$ In the MAGPIE trial, the risk of pulmonary edema was similar in the $\mathrm{Mg}$ and placebo groups (0.63 and $0.65 \%$, respectively). ${ }^{36}$

\section{Dysmagnesemia \\ Hypomagnesemia}

Hypomagnesemia, defined as a plasma concentration below $0.7 \mathrm{mmol} \cdot \mathrm{L}^{-1}$, is considered severe when under $0.5 \mathrm{mmol} \cdot \mathrm{L}^{-1}$. This condition is most often associated with a true depletion of $\mathrm{Mg}$ in the organism, although 
a $\mathrm{Mg}$ deficit can exist even when magnesemia is normal. Thus, measurement of the urinary excretion of $\mathrm{Mg}$ and possibly a loading test can help establish the diagnosis. ${ }^{37}$ As the bone and intracellular $\mathrm{Mg}$ reserves of the organism cannot be easily mobilized toward the extracellular sector, a negative $\mathrm{Mg}$ balance rapidly leads to hypomagnesemia. ${ }^{6}$

A deficit was found in 11,19 and $47 \%$ of blood samples obtained from hospitalized patients with increasing $\mathrm{Mg}$ thresholds of $<0.6 \mathrm{mmol} \cdot \mathrm{L}^{-1},<0.62$ and $<0.74 \mathrm{mmol} \cdot \mathrm{L}^{-1}$ respectively. ${ }^{38-40}$ The incidence of deficit was much higher in patients sampled in surgical and medical intensive care units, reaching 61 and $65 \%$ for thresholds of 0.75 and $0.7 \mathrm{mmol} \cdot \mathrm{L}^{-1}$ respectively. ${ }^{41,42}$ The high rates for these patients were due to an association of several causes of hypomagnesemia. This disorder is often overlooked, although it should probably be searched for systematically because of its significance for the prognosis of patients. ${ }^{40}$ In fact, a prospective study of patients hospitalized in wards and intensive care units (ICU) showed that the death rate was twice as high for the group with hypomagnesemia on admission as for the group without a deficit but an equivalent APACHE II score. ${ }^{39}$ These data were confirmed by Chernow et al. in a study of postoperative ICU patients, for whom the death rate was $41 \%$ vs $13 \%$ for patients without hypomagnesemia. ${ }^{41}$ Other studies after heart surgery showed that patients with hypomagnesemia experienced more rhythm disorders. Time on the ventilator was longer, ${ }^{16,43}$ and morbidity was higher than for patients with normal magnesemia. ${ }^{43}$ Another study showed that a greater than $10 \%$ reduction of serum and intracellular concentrations was associated with a higher rate of postoperative ventricular arrhythmias. ${ }^{17}$

As the regulation of $\mathrm{Mg}$ homeostasis is ensured by the digestive tube or the kidney, the main causes of hypomagnesemia are digestive (lack of input or absorption, or excessive elimination) or renal (increased excretion), as summarized in Table I. ${ }^{6}$

In human clinical conditions, it is difficult to define the symptomatology of hypomagnesemia specifically, as it is often associated with other metabolic disorders. For example, a $\mathrm{Mg}$ deficit was associated with a potassium deficit in $61 \%$ of patients with hypokalemia. ${ }^{40}$ Administration of potassium alone often fails to remedy kalemia, and only simultaneous correction of $\mathrm{Mg}$ and potassium deficits restores normal levels. The role of $\mathrm{Mg}$ in transmembrane potassium transport systems accounts for this phenomenon. ${ }^{44} \mathrm{~A}$ calcium deficit is also often associated with a severe $\mathrm{Mg}$ deficit.

When experimental $\mathrm{Mg}$ depletion is induced in human volunteers, the clinical manifestations and metabolic abnormalities of Mg deficiency are anorexia, generalized weakness, positive Trousseau and Chvostek signs, hypokalemia and hypocalcemia. ${ }^{6}$ The main clinical manifestations of hypomagnesemia are summarized in Table II.

Oral administration of 5 to $15 \mathrm{mmol} \cdot \mathrm{day}^{-1}$ is sufficient to eliminate moderate deficits and can be increased to 15 to $28 \mathrm{mmol} \cdot \mathrm{day}^{-1}$ for severe deficits. The usual $i v$ dose is $25 \mathrm{mmol}$ administered as a continuous infusion in eight to $24 \mathrm{hr}^{6}{ }^{6}$ In severe, but non-lifethreatening hypomagnesemia, it is advisable to begin with an infusion of 1 to $2 \mathrm{~g} \cdot \mathrm{hr}^{-1}$ of $\mathrm{Mg}$ sulfate for three to six hours and then decrease the rate to 0.5 to $1 \mathrm{~g} \cdot \mathrm{hr}^{-1}$ as a maintenance infusion. In the treatment of acute life-threatening arrhythmias, it is advisable to inject 1 to $2 \mathrm{~g}(4-8 \mathrm{mmol})$ of $i v \mathrm{Mg}$ sulfate over five minutes. This

\section{TABLE I Causes of hypomagnesemia}

\begin{tabular}{l}
\hline Gastrointestinal causes \\
Decreased intake \\
Chronic alcoholism \\
Malnutrition \\
Prolonged administration of magnesium-free \\
intravenous fluids \\
Decreased absorption \\
Short bowel syndrome \\
Small bowel bypass surgery \\
Malabsorption \\
Inflammatory bowel disease \\
Primary intestinal hypomagnesemia \\
Gastrointestinal losses \\
Vomiting \\
Prolonged nasogastric suction \\
Acute or chronic diarrhea \\
Biliary or intestinal fistula \\
Acute pancreatitis \\
Chronic laxative abuse \\
Renal causes: increased urinary excretion \\
Chronic alcoholism \\
Diuretics \\
Diuretic phase of acute tubular necrosis \\
Post-obstructive diuresis \\
Post-renal transplantation \\
Nephrotoxic drugs: aminoglycoside antibiotics, amphotericin \\
B, cisplatin, cyclosporine, pentamidine \\
Hypercalcemia \\
Primary hyperparathyroidism \\
Bartter's syndrome \\
Gitelman's syndrome \\
Primary renal magnesium wasting \\
Hyperaldosteronism \\
Miscellaneous \\
Diabetes mellitus \\
Hnsulin infusion \\
Hungry boparathyroidism dialysis \\
\hline
\end{tabular}


TABLE II Signs and symptoms of hypomagnesemia

\begin{tabular}{|c|c|}
\hline General signs: & $\begin{array}{l}\text { Generalized weakness } \\
\text { Anorexia } \\
\text { Apathy, depression }\end{array}$ \\
\hline Neuromuscular signs: & $\begin{array}{l}\text { Chvostek's and Trousseau's signs } \\
\text { Muscular fasciculations and cramps } \\
\text { Tremor } \\
\text { Tetany } \\
\text { Generalized convulsions } \\
\text { Respiratory muscle weakness or paralysis }\end{array}$ \\
\hline Cardiovascular signs: & $\begin{array}{l}\text { Cardiac arrhythmias: } \\
\text { Frequently: torsades de pointes, } \\
\text { ventricular tachycardia } \\
\text { Supra- and ventricular arrhythmias } \\
\text { Digitalis-associated arrhythmias } \\
\text { Hypertension } \\
\text { Sudden death } \\
\text { Coronary artery vasospasm } \\
\text { Progressive changes in the } \\
\text { electrocardiogram: } \\
\text { Widening of the QRS complex and } \\
\text { peaking of the T wave } \\
\text { Prolongation of the PR interval } \\
\text { and flattening of the T wave }\end{array}$ \\
\hline Metabolic abnormali & $\begin{array}{l}\text { s: Hypokalemia } \\
\text { Hypocalcemia } \\
\text { Metabolic alkalosis }\end{array}$ \\
\hline
\end{tabular}

bolus should be followed by an infusion of 1 to $2 \mathrm{~g}$ of $\mathrm{Mg}$ sulfate per hour for the next few hours and then be reduced to 0.5 to $1 \mathrm{~g} \mathrm{Mg}$ sulfate per hour as a maintenance infusion. Potassium and $\mathrm{Mg}$ levels should be monitored during therapy. These dosages should be reduced in patients with renal insufficiency. ${ }^{9}$

\section{Hypermagnesemia}

Hypermagnesemia, which is less frequent than hypomagnesemia, was found in 9.3, 5.7 and $3.5 \%$ of blood samples obtained from hospitalized patients with increasing $\mathrm{Mg}$ thresholds of $>0.95 \mathrm{mmol} \cdot \mathrm{L}^{-1},>0.99$ and $>1.07 \mathrm{mmol} \cdot \mathrm{L}^{-1}$ respectively. ${ }^{38,40}$ In postoperative intensive care, hypermagnesemia was observed in $5.2 \%$ of patients with a threshold of $1 \mathrm{mmol} \cdot \mathrm{L}^{-1} .41$ Moderate hypermagnesemia is frequent in patients with chronic renal insufficiency, ${ }^{2}$ both during rhabdomyolysis (due to release of $\mathrm{Mg}$ from disintegrating muscle) and after excessive use of antacids or laxatives containing $\mathrm{Mg}$ salts. ${ }^{45}$ Severe hypermagnesemia is most often observed during the therapeutic administration of $\mathrm{Mg}$ sulfate in patients with chronic renal insufficiency or during treatment of eclampsia. ${ }^{34}$
Neuromuscular and cardiovascular manifestations are predominant in the clinical symptomatology of hypermagnesemia. However, clinical severity is not always correlated with the degree of hypermagnesemia. ${ }^{34}$ Flushing, nausea and/or vomiting can be early signs. Central neurological signs range from somnolence to deep coma. Deep tendon reflexes may be reduced or totally lost. Breathing may be decreased or even stopped because of paralysis of the respiratory muscles. Cardiovascular abnormalities may include hypotension because of peripheral vasodilatation, conduction disorders (lengthening of the PR and/or QT intervals or the QRS complex, and atrioventricular block), bradycardia and even cardiac arrest. ${ }^{10}$

Treatment is based on stopping $\mathrm{Mg}$ inputs. An infusion of calcium salts, which momentarily antagonizes some $\mathrm{Mg}$ effects, can be initiated in emergency conditions $(2.5-5 \mathrm{mmol}$ in a slow $i v$ infusion until disappearance of conduction disorders) when neurological and cardiovascular complications are life-threatening. ${ }^{9,10,28,29}$ Loop diuretics inhibit renal reabsorption of $\mathrm{Mg}$ and induce an increased urinary excretion of $\mathrm{Mg}$, but also of calcium, which can cause hypocalcemia and thereby intensify the clinical signs of hypermagnesemia. Calcemia needs to be monitored, and some authors recommend preventive administration of calcium salts when diuretics are used. For patients with renal insufficiency, recourse to dialysis involving a Mg-poor fluid is frequent.

\section{Therapeutic indications for $\mathbf{M g}$ in anesthesiology Anesthetic induction}

The stress of intubation is associated with catecholamine release. $\mathrm{Mg}$ reduces this release by the adrenal medulla and adrenergic nerve endings. In a comparative study, patients received thiopental and succinylcholine with or without $\mathrm{Mg}$ sulfate $60 \mathrm{mg} \cdot \mathrm{kg}^{-1}$ at anesthesia induction. Patients treated with $\mathrm{Mg}$ showed a lower increase of heart rate and systolic blood pressure after intubation. Plasma concentrations of epinephrine and norepinephrine were markedly lower after intubation in the Mg-treated group. ${ }^{46}$

In a prospective study concerning coronary patients, Puri et al. compared hemodynamic changes during anesthesia induction and intubation after infusion of $\mathrm{Mg}$ or lidocaine. The group treated with $\mathrm{Mg}$ showed a slight increase in mean arterial pressure (MAP) and systemic vascular resistance and no decrease in cardiac output, as compared to the lidocaine group, with equally good control of increased heart rate. ${ }^{47}$ In another study, the group treated with $\mathrm{Mg}$ showed a lesser hypertensive response during induction compared to placebo, whereas early reflex 
tachycardia was not controlled by $\mathrm{Mg} .{ }^{48}$ Ashton et al. found no increase in arterial pressure or heart rate and a moderate decrease of plasma catecholamine concentrations after intubation in a group treated with $\mathrm{Mg}$ alone before intubation. ${ }^{49}$ In all these studies, $\mathrm{Mg}$ administration before anesthesia induction was associated with a good control of the adrenergic response during intubation.

\section{Surgery for pheochromocytoma}

The use of $\mathrm{Mg}$ in pheochromocytoma surgery is based on the inhibitory action of catecholamine reuptake by the adrenal medulla, which reduces the sensitivity of aadrenergic receptors in the context of peripheral vasodilatation and decreases antiarrhythmic effects..$^{50,51}$

Several clinical cases have demonstrated the advantage of supplementing conventional treatment with $\mathrm{Mg}$ sulfate to improve control of arterial pressure and heart rate. Hemodynamic balance was achieved during anesthesia induction and intubation, but frequently remained unstable during tumour resection. ${ }^{51-53}$ In a study of 17 cases, James clearly showed that catecholamine concentrations were reduced after $\mathrm{Mg}$ infusion and, especially, that they did not increase after intubation. However, $\mathrm{Mg}$ did not prevent a considerable rise in cathecolamine levels at the time of tumour resection. Before tumour removal, control of arterial pressure and heart rate was obtained in 12 cases after the infusion of $\mathrm{Mg}$ alone. For four of the other five patients, sodium nitroprusside was required to control arterial pressure at the time of tumour handling, including one case in which phentolamine was added. The patient for whom hemodynamic control could not be obtained had a serum $\mathrm{Mg}$ concentration $\left(1.3 \mathrm{mmol} \cdot \mathrm{L}^{-1}\right)$ below desired values, which may have been responsible for clinical failure. Serum $\mathrm{Mg}$ concentrations were high in the other patients (2-4 $\left.\mathrm{mmol} \cdot \mathrm{L}^{-1}\right)$, corresponding to inputs of 8 to $18 \mathrm{~g}$ of $\mathrm{Mg}$ in a period of 60 to $150 \mathrm{~min} .^{50,54}$

With such high doses and serum concentrations of $\mathrm{Mg}$, the effects of curares were increased and it was necessary to counteract these at the end of the operation, before extubation. ${ }^{50,51}$ After tumour resection, vascular filling generally allowed correction of low arterial pressure ${ }^{51}$ so that recourse to vasopressors was only necessary in one of the 17 cases studied by James. ${ }^{50}$ As this type of surgery is infrequent, no controlled prospective study has evaluated the role of $\mathrm{Mg}$ during surgery for pheochromocytoma.

\section{Cardiac surgery}

The high rate of hypomagnesemia after cardiac surgery is well established. ${ }^{14-16,43}$ Lower serum $\mathrm{Mg}$ levels have been found to be associated with an increased incidence of atrial fibrillation, ${ }^{43,55,56}$ which was decreased in several studies by the prophylactic administration of $\mathrm{Mg}$ after coronary artery bypass grafting. ${ }^{14,15,56,57}$ In a group treated with $\mathrm{Mg}$ postoperatively, England et al. found a non-significant reduction of supraventricular dysrhythmias, a significant decrease of ventricular dysrhythmias and a significant increase of postoperative cardiac indices. ${ }^{43}$ There were no differences between groups for the various forms of ventricular arrhythmia. ${ }^{14}$ Two other studies including only small numbers of patients found a non-significant reduction of postoperative atrial fibrillation ${ }^{27}$ or rhythm disorders. ${ }^{58}$ One study reported no decrease of postoperative atrial tachyarrhythmias, although $\mathrm{Mg}$ was only initiated postoperatively. ${ }^{59}$ Among the four studies with positive results, $\mathrm{Mg}$ was initiated postoperatively in one, ${ }^{14}$ and intraoperatively in the other three. ${ }^{15,56,57}$

A high rate of postoperative hypomagnesemia has also been observed in pediatric heart surgery. Junctional ectopic tachycardia occurred in $27 \%$ of children who were not given $\mathrm{Mg}$ postoperatively, whereas those who received $\mathrm{Mg}$ had no rhythm disorders. ${ }^{60}$

With respect to its vascular properties, the role of $\mathrm{Mg}$ has been studied in the context of controlling intraoperative hypertension. In a population of hypertensive patients who underwent cataract surgery under local anesthesia, a comparative study showed that preoperative administration of $\mathrm{Mg}$ ( $v s$ placebo) allowed stabilization of intraoperative variations in systolic and diastolic pressures. ${ }^{58}$ In cardiac surgery, $\mathrm{Mg}$ has proved to be as efficient as nicardipine in controlling arterial pressure during cardiopulmonary bypass procedures. As cardiopulmonary bypass output was constant, the reduction of MAP observed was attributed to decreased systemic arterial resistance. ${ }^{27}$

As $\mathrm{Mg}$ has a stabilizing effect on membranes, it can be used in the treatment of cardiac rhythm disorders. The best indication is for the treatment of torsades de pointes, ${ }^{61}$ but $\mathrm{Mg}$ is also indicated for ventricular arrhythmias related to digitalis toxicity. ${ }^{4}$ In critically ill patients, Mg proved more effective than amiodarone for the conversion of acute atrial tachyarrhythmias. ${ }^{62}$

\section{Obstetric anesthesia}

High $\mathrm{Mg}$ doses produce a tocolytic and hypotensive effect in preeclampsia. ${ }^{32,63,64} \mathrm{In}$ an animal model, $\mathrm{Mg}$ lowered maternal arterial pressure, while maintaining uterine arterial flow and fetal oxygenation. ${ }^{65} \mathrm{Mg}$ has an inhibitory effect on NMDA receptors and increases the production of vasodilator prostaglandins, thereby affecting cerebral vasodilatation. ${ }^{66,67} \mathrm{Mg}$ causes vasodilatation of smaller-diameter intracranial vessels in patients with preeclampsia, ${ }^{68}$ which could account 
for its anticonvulsant action. ${ }^{66,67}$

The risk of onset of eclampsia in women with severe preeclampsia is about 1 to $3 \%{ }^{69}$ Compared to placebo, administration of $\mathrm{Mg}$ was found to reduce the incidence of convulsions in this population. ${ }^{69}$ An earlier work had reported no difference, but the number of patients in the two groups was low. ${ }^{70} \mathrm{Mg}$ was more efficient than phenytoin in preventing the onset of convulsive seizures. ${ }^{71}$ However, no difference was observed between $\mathrm{Mg}$ and phenytoin groups in two other studies with low numbers of subjects. ${ }^{72,73}$ The meta-analysis of Chien et al. found that $\mathrm{Mg}$ was superior to phenytoin in this population. ${ }^{74}$ These data have been confirmed by the recent results of the Magpie Trial, which found a $58 \%$ reduction of the risk of eclampsia for $\mathrm{Mg}$ vs placebo. ${ }^{36}$ The recommended doses are $4 \mathrm{~g}$ of $\mathrm{Mg}$ sulfate infused in $20 \mathrm{~min}$, followed by a continuous infusion at a rate of 1 to $2 \mathrm{~g} \cdot \mathrm{hr}^{-1} \cdot 66,69$

In a multicentre prospective study including nearly 1,700 women with eclampsia, $\mathrm{Mg}$, as compared to diazepam and phenytoin, did not reduce maternal death but decreased the recurrence of convulsions and of neonatal morbidity. Labour lasting more than eight hours was slightly more frequent in the group treated with $\mathrm{Mg}$, but $\mathrm{Mg}$ had no incidence on the rate of Cesarean delivery, blood loss and transfusion. ${ }^{67}$ Two studies found a decrease in recurrent convulsions in the group treated with $\mathrm{Mg}$ as compared to those treated with diazepam and phenytoin, but the difference was not significant because of the low number of patients involved. ${ }^{33,75}$ The meta-analysis by Chien $e t$ al. found a significant reduction of recurrent convulsions in patients treated with $\mathrm{Mg}$ as compared to diazepam and phenytoin. ${ }^{74}$

$\mathrm{Mg}$ administered to the mother may have a neuroprotective effect for the newborn. Neonatal morbidity was lower and an Apgar score below 7 at one minute was significantly less frequent in infants of mothers treated by $\mathrm{Mg}$ as compared to diazepam. ${ }^{33}$ The multicentre study referred to above found a decrease in neonatal morbidity when $\mathrm{Mg}$ was used at the doses administered for eclampsia (loading dose of $4 \mathrm{~g} i \mathrm{v}$ followed by an infusion of $\mathrm{l} \mathrm{g} \cdot \mathrm{hr}^{-1}$ or $\mathrm{im}$ administration of $5 \mathrm{~g}$ every four hours).$^{67} \mathrm{In}$ a population of low birth weight infants, maternal treatment with $\mathrm{Mg}$ before delivery was associated with a reduced risk of cerebral palsy $^{76}$ and a decrease of ultrasonographically detected lesions of cystic periventricular leukomalacia. ${ }^{77}$ This neuroprotective effect of $\mathrm{Mg}$ in premature infants was not found in other studies. ${ }^{77-80}$ The discrepancies in the results of these retrospective studies led several researchers to undertake prospective studies. One of these investigations was discontinued early because of a significant increase in the deaths of newborns whose mothers had been given $\mathrm{Mg}$ at tocolytic doses (loading dose of $4 \mathrm{~g}$ followed by infusion of $\left.2-3 \mathrm{~g} \cdot \mathrm{hr}^{-1}\right){ }^{81}$ A correlation seemed likely between high ionized $\mathrm{Mg}$ concentrations in cord blood and death. ${ }^{82}$ However, an abnormally low death rate was noted in the control group, and the deaths occurring in the $\mathrm{Mg}$ group were often attributable to marked prematurity. ${ }^{81}$

$\mathrm{Mg}$ can be recommended for anticonvulsant treatment, ${ }^{35}$ and the studies cited above confirm its effica$\mathrm{cy}$ in preeclampsia and eclampsia. However, data to date seem inadequate to determine its usefulness and safety at higher (tocolytic) doses. ${ }^{32}$

\section{Interaction of $\mathrm{Mg}$ with drugs used in anesthesia and intensive care}

A lengthening of neuromuscular blockade has been reported in patients treated by $\mathrm{Mg}$ and confirmed experimentally. ${ }^{83}$ In two prospective studies, a lower use of curare during surgery was observed in the group treated with $\mathrm{Mg} .{ }^{12,84} \mathrm{Mg}$ blockade at the neuromuscular junction is the result of (i) a reduction of the amount of acetylcholine released from motor nerve terminals; (ii) a decrease in the depolarizing action of acetylcholine at the endplate; or (iii) depression of muscle fibre membrane excitability. ${ }^{83}$ In a rat phrenic nerve-diaphragm preparation, $\mathrm{Mg}$ potentiated neuromuscular blockade produced by d-tubocurarine, decamethonium and succinylcholine. ${ }^{83}$ Prolonged curarization may require more frequent recourse to anticholinesterases to counteract neuromuscular blockade. ${ }^{11,83}$

In a halothane anesthetized rat model, continuous infusion of $\mathrm{Mg}$ led to a reduction of halothane minimum alveolar concentration, which was nonlinearly dependent on plasma $\mathrm{Mg}$ level. ${ }^{85}$ Volatile anesthetic effects on NMDA receptors can be potentiated significantly by $\mathrm{Mg}$, ketamine, or most profoundly by both. The analgesic effects of ketamine and $\mathrm{Mg}$ are likely to be enhanced in the presence of volatile anesthetics. ${ }^{86}$

Hypomagnesemia increased ketamine sensitivity in a rat $\mathrm{Mg}$ deficiency model. ${ }^{87}$ NMDA receptors are important components of pain processing, and their response can be inhibited by ketamine and $\mathrm{Mg}$, which have a super-additive effect in combination. This may explain in part why analgesia is more effective for the combination than for either compound alone. ${ }^{88}$

The vasodilator properties of $\mathrm{Mg}$ theoretically increase the risk of hypotension and this risk could be augmented by the vasoplegic effects of anesthetics drugs or during epidural anesthesia. ${ }^{66,85}$ In epidural anesthesia of gravid ewes, an initial high dose of $\mathrm{Mg}$ sulfate decreased maternal MAP, but increased uterine artery blood flow and fetal $\mathrm{PaO}_{2} \cdot{ }^{65}$ In large studies in 
humans, the risk of hypotension was moderately increased compared to placebo $(0.75$ vs $0.4 \%)$ when half of the patients in each group had received concomitantly antihypertensive drugs. ${ }^{36}$ The clinical manifestations of hypermagnesemia included hypotension. ${ }^{10,28}$

Clinical situations in which glycemia remains elevated despite increased insulin doses are frequent in intensive care. In fact, insulin resistance increases as the serum $\mathrm{Mg}$ concentration decreases, with $\mathrm{Mg}$ acting as a second messenger for insulin. ${ }^{2}$ Diuretics increase renal excretion of $\mathrm{Mg}$ and can cause hypomagnesemia. ${ }^{2}$ Gentamicin treatment can also induce hypomagnesemia through renal loss of $\mathrm{Mg}$, which ceases once treatment is stopped. ${ }^{2}$

\section{Perioperative analgesia}

The use of $\mathrm{Mg}$ as an adjuvant in the context of perioperative analgesia is novel. This application is based on the antagonist properties of $\mathrm{Mg}$ for the NMDA receptor and its inhibitory properties for calcium channels. Calcium channel blockers have shown antinociceptive effects in animals and morphine potentiation in patients with chronic pain. NMDA receptor antagonists can prevent the induction of central sensitization due to peripheral nociceptive stimulation and abolish hypersensitivity. ${ }^{11}$

The double-blind prospective study of Tramèr $e t a l$. clearly shows the value of $\mathrm{Mg}$ as an adjuvant in postoperative analgesia. Patients receiving $\mathrm{Mg}$ required less morphine, had less discomfort and slept better during the first $48 \mathrm{hr}$ than those receiving morphine alone. The quality of postoperative analgesia was, of course, equivalent. Three respiratory depressions occurred in the patient-controlled analgesia group receiving morphine only $v s$ none in the group treated by morphine and Mg. ${ }^{11}$ Koinig et al. reported similar results, with a reduction of analgesic use both intra- and postoperatively in the group receiving $\mathrm{Mg}$ pre- and intraoperatively. ${ }^{13}$ In both studies, plasma $\mathrm{Mg}$ concentration was markedly reduced postoperatively in the control group (values close to hypomagnesemia), but was significantly increased in the treatment group. ${ }^{11,13}$

Wilder-Smith et al. conducted a comparative study of pain intensity and postoperative use of morphine in three groups. In each group, patients received ketamine, $\mathrm{Mg}$ or fentanyl pre- and intraoperatively. No differences were found between groups for the effects of these products. ${ }^{89}$

In another report, $\mathrm{Mg}$ infusion after anesthesia induction reduced intraoperative use of remifentanyl. $^{84}$ In two other studies, the trend toward reduced use of fentanyl intraoperatively ${ }^{90}$ and morphine postoperatively ${ }^{90,91}$ was confirmed, but not sta- tistically significant. In the study of Wilder-Smith et al., lack of significance was probably due to the low numbers of patients in the groups. ${ }^{91}$

Ko et al. found no reduction of analgesic use during the postoperative period. However, $\mathrm{Mg}$ was the only analgesic used intraoperatively in their treatment group and only initiated after anesthesia induction. ${ }^{12}$

It seems clear that $\mathrm{Mg}$ reduces the use of classic morphine-based drugs, as well as their side effects, when administered pre- and intraoperatively and associated with these drugs during the operation. Future studies will undoubtedly define the precise role of $\mathrm{Mg}$ as adjuvant in perioperative analgesia.

A recent study suggested that the intrathecal administration of $\mathrm{Mg}$ sulfate might be a useful adjunct to spinal morphine analgesia in a rat model..$^{92}$ These findings could lead to studies defining the benefit of adjuvant $\mathrm{Mg}$ in obstetrical or postoperative analgesia.

\section{Myocardial infarction}

Two meta-analyses studied the impact of $\mathrm{Mg}$ treatment on reduction of the death rate and rhythm disorders in the acute phase of myocardial infarction before initiation of reperfusion treatments. Both reports found a $54 \%$ reduction of the death rate, ${ }^{93,94}$ and one noted a decreased incidence ( $49 \%$ less) of ventricular fibrillation or tachycardia in the population treated by $\mathrm{Mg} .{ }^{93}$ Several mechanisms of $\mathrm{Mg}$ action were proposed, as the death rate observed corresponded to the expected rate: coronary and systemic vasodilatation, prevention of rhythm disorders, reduction of platelet aggregation, and improvement of myocardial metabolism. ${ }^{93} \mathrm{~A}$ recent study not involving reperfusion therapy confirmed these data, showing a reduction of rhythm disorders and the death rate. These authors found that serum $\mathrm{Mg}$ levels of patients with acute myocardial infarction were lower than those of controls. ${ }^{95}$

Since the appearance of reperfusion techniques, the results of studies have been divergent. The LIMIT-2 trial found a reduction of the death rate and left-ventricular failure at 28 days and a lower death rate at four years for patients treated early with $\mathrm{Mg} .{ }^{96,97}$ Subsequently, the ISIS-4 trial, including more than 58,000 patients, found a non-significant increase of the death rate at five weeks and one year in the group treated with $\mathrm{Mg}$. Ventricular fibrillation was reduced in the treatment group, whereas other forms of cardiac arrest (heart failure and cardiogenic shock) were increased. ${ }^{98}$ Methodological differences may account for these conflicting results. In the ISIS-4 trial, the death rate in the control group was low, and $\mathrm{Mg}$ was administered later (after reperfusion). Therefore, a 
study has recently been initiated to include 10,400 high-risk patients for whom $\mathrm{Mg}$ treatment will be started early.99 The recently published results of this study confirm the ISIS- 4 data. In a population of high-risk patients with acute myocardial infarction, early $\mathrm{Mg}$ treatment was neither beneficial nor harmful and failed to decrease the 30-day mortality and the need for treatment of heart failure or dysrrhythmias. ${ }^{100}$ The usefulness of $\mathrm{Mg}$ treatment in acute myocardial infarction appears to be controversial.

\section{Cardiac arrest}

Retrospective reports have described successful resuscitation after $\mathrm{Mg}$ administration in refractory cases. In a randomized trial, a 5-g $\mathrm{Mg}$ sulfate bolus vs placebo failed to improve the return of spontaneous circulation, survival after emergency department management and survival to hospital discharge. The main limitation of this study was the small size of the groups. ${ }^{101}$ A second study comparing a 2 -g bolus followed by $24 \mathrm{hr}$ infusion $(8 \mathrm{~g})$ to placebo failed to improve the same endpoints. However, the median Karnofsky index was higher in patients who had received $\mathrm{Mg}$ and survived to hospital discharge. More of these patients were capable of independent living after discharge, which suggests that $\mathrm{Mg}$ may have a cerebral protective effect. ${ }^{102}$

\section{Asthma}

$\mathrm{Mg}$ has bronchodilator effects apparently related to its calcium antagonist properties that inhibit the contraction of smooth muscle fibres. ${ }^{103}$

Three meta-analyses have recently been published on this subject. ${ }^{103-105}$ That of Alter et al. (based on nine studies) determined that addition of $\mathrm{Mg}$ sulfate $v s$ placebo to conventional asthma treatment led to a $16 \%$ improvement of peak flow. ${ }^{104}$ The meta-analysis of Rowe et al. (based on seven studies) found that iv administration of $\mathrm{Mg}$ significantly reduced the length of hospital stays and improved the peak expiratory flow (PEF) rate, as compared to placebo, in the subgroup of patients with severe asthma treated in the emergency department. ${ }^{103}$ In the different studies, $\mathrm{Mg}$ was administered as a loading dose by infusion of 1.2 or $2 \mathrm{~g}$ in $20 \mathrm{~min}$, after initiation of treatment with oxygen, $B$-agonists, anticholinergic agents and corticosteroids. ${ }^{103}$ The third meta-analysis (based on five studies) found that the very slight improvement of pulmonary function after $\mathrm{Mg}$ infusion and the decrease of the hospitalization rate were not significant compared to results for placebo groups. ${ }^{105}$

Several observations can be made about these meta-analyses and the studies concerned. That of Rodrigo et al. ${ }^{105}$ included only five studies, two of which gave negative results, whereas two pediatric studies with positive results were excluded. ${ }^{106,107}$ Moreover, the patient populations were not homogeneous. Two of the studies concerned pediatric asthmatic populations ${ }^{106,107}$ and another a population with exacerbation of chronic obstructive pulmonary disease. All of the studies except one ${ }^{108}$ used $\mathrm{Mg}$ sulfate as second-line therapy in patients who had usually not responded to conventional treatment. It is noteworthy that in the only study comparing $\mathrm{Mg}$ inhalation with salbutamol inhalation an equivalent bronchodilator effect was observed for both treatments, with an improvement in PEF of 35 and $42 \%$ respectively. ${ }^{108}$

The role of $\mathrm{Mg}$ in the treatment of bronchospasm is controversial, but there appears to be a bronchodilator effect that improves PEF and reduces the hospitalization rate for asthmatic patients seen in emergency departments. These effects appeared to be more marked in a subpopulation with severe asthma that failed to respond to conventional therapy. ${ }^{106,107,109-111} \mathrm{~A}$ prospective study including a large number of patients in this subpopulation would be useful to confirm the role of $\mathrm{Mg}$ as a bronchodilator as second-line therapy and in association with conventional treatment.

$\mathrm{Mg}$ should not be used routinely in the treatment of moderate asthma, but $i v \mathrm{Mg}$ sulfate may be useful in addition to the usual therapy for refractory asthma. ${ }^{5,30,112}$

\section{Prospects}

Recent studies could lead to the establishment of new indications for $\mathrm{Mg}$. In patients with tetanus, $\mathrm{Mg}$ infused at doses providing serum concentrations of 2 to $4 \mathrm{mmol} \cdot \mathrm{L}^{-1}$ allowed good control of spasms and muscle rigidity. Intubation and ventilation were only required for $43 \%$ of patients, and the overall death rate was $12 \% .{ }^{113}$

Fluoroquinolones, which are toxic for tendons and cartilage, are $\mathrm{Mg}$ ion chelators largely involved in cartilage biochemistry. A recent animal study found that fluoroquinolones induced a high rate of cartilaginous lesions in immature rats with $\mathrm{Mg}$ deficiency, whereas rats without deficiency had no lesions. ${ }^{114}$ A correction of hypomagnesemia might be necessary in this context.

$\mathrm{Mg}$ or calcium deficiency seems likely in those patients treated by oxaliplatin who show neurotoxic clinical side effects characteristic of tetany or myotonia. The toxicity of oxaliplatin for the neuron is related to a decrease in the inward sodium current amplitude resulting in a reduction of the action potential amplitude, e.g., in the case of calcium chelating substances. The role of $\mathrm{Mg}$ or calcium in preventing oxaliplatin neurotoxicity has been suggested, ${ }^{115}$ and a 
prospective study has been initiated to confirm the neuroprotective effects of calcium and $\mathrm{Mg}$.

\section{Conclusion}

Hypomagnesemia is frequent postoperatively and in the intensive care unit. As hypomagnesemia is responsible for increased morbidity and mortality, it should be detected and corrected systematically. Hypermagnesemia is relatively infrequent and often iatrogenic, particularly in the case of patients with renal insufficiency, for whom $\mathrm{Mg}$ should be prescribed with care.

$\mathrm{Mg}$ can be used in anesthesia during induction or pheochromocytoma surgery in order to control adrenergic response. It can reduce the incidence of postoperative rhythm disorders in cardiac surgery and prevent the onset or recurrence of convulsive seizures in preeclampsia and eclampsia. It could also be used more extensively as an adjuvant in perioperative analgesia. It is of particular importance to understand how $\mathrm{Mg}$ interacts with the therapeutic drugs used in anesthesia and intensive care.

$\mathrm{Mg}$ is used for its antiarrhythmic properties in treating torsades de pointes and arrhythmias induced by digitalis. Its role in the treatment of asthmatic attacks and myocardial infarction needs to be defined more precisely.

$\mathrm{Mg}$ can be used as second-line therapy in various clinical situations, particularly in hypertensive attacks for its vasodilator properties, in the correction of hypokalemia, and in situations involving insulin resistance.

\section{Acknowledgements}

The authors are grateful to Prof. Delhumeau and Prof. Beydon for assistance in the preparation of this manuscript.

\section{References}

1 Delhumeau A, Granry JC, Monrigal J-P, Costerousse $F$. Therapeutic use of magnesium in anaesthesia and intensive care (French). Ann Fr Anesth Réanim 1995; 14: 406-16.

2 Sanders GT, Huijgen HJ, Sanders R. Magnesium in disease: a review with special emphasis on the serum ionized magnesium. Clin Chem Lab Med 1999; 37: 1011-33.

3 Saris NE L, Mervaala E, Karppanen H, Khawaja JA, Lewenstam A. Magnesium. An update on physiological, clinical and analytical aspects. Clinica Chimica Acta 2000; 294: 1-26.

4 Fawcett WJ, Haxby EJ, Male DA. Magnesium: physiology and pharmacology. Br J Anaesth 1999; 83: 302-20.
5 Dacey MJ. Hypomagnesemic disorders. Crit Care Clin 2001; 17: 155-73.

6 Kelepouris E, Agus ZS. Hypomagnesemia: renal magnesium handling. Semin Nephrol 1998; 18: 58-73.

7 Quamme GA. Renal magnesium handling: new insights in understanding old problems. Kidney Int 1997; 52: 1180-95.

8 De Rouffignac C, Quamme G. Renal magnesium handling and its hormonal control. Physiol Rev 1994; 74: 305-22.

9 Zaloga GP, Chernow B. Divalent ions: calcium, magnesium, and phosphorus. In: Chernow B (Ed.). The Pharmacologic Approach to the Critically Ill Patient, 3rd ed. Baltimore: Williams and Wilkins Inc.; 1994: 777-804.

10 Swain R, Kaplan-Machlis B. Magnesium for the next millennium. South Med J 1999; 92: 1040-7.

11 Tramèr MR, SchneiderJ, Marti RA, Rifat K. Role of magnesium sulfate in postoperative analgesia. Anesthesiology 1996; 84: 340-7.

12 Ko SH, Lim HR, Kim DC, Han YJ, Choe H, Song $H S$. Magnesium sulfate does not reduce postoperative analgesic requirements. Anesthesiology 2001; 95: 640-6.

13 Koinig H, Wallner T, Marhofer P, Andel H, Hörauf $K$, Mayer N. Magnesium sulfate reduces intra- and postoperative analgesic requirements. Anesth Analg 1998; 87: 206-10.

14 Fanning WJ, Thomas CS Jr, Roach A, Tomicheck R, Alford WC, Stoney WS Jr. Prophylaxis of atrial fibrillation with magnesium sulfate after coronary artery bypass grafting. Ann Thorac Surg 1991; 52: 529-33.

15 Speziale G, Ruvolo G, Fattouch K, et al. Arrhythmia prophylaxis after coronary artery bypass grafting: regimens of magnesium sulfate administration. Thorac Cardiovasc Surg 2000; 48: 22-6.

16 Aglio LS, Stanford GG, Maddi R, Boyd JL III, Nussbaum S, Chernow B. Hypomagnesemia is common following cardiac surgery. J Cardiothorac Vasc Anesth 1991; 5: 201-8.

17 Zuccala G, Pahor M, Lattanzio F, et al. Detection of arrhythmogenic cellular magnesium depletion in hip surgery patients. Br J Anaesth 1997; 79: 776-81.

18 Reinhart $R A$. Clinical correlates of the molecular and cellular actions of magnesium on the cardiovascular system. Am Heart J 1991; 121: 1513-21.

19 Kafiluddi R, Kennedy RH, Seifen E. Effects of buffer magnesium on positive inotropic agents in guinea pig cardiac muscle. Eur J Pharmacol 1989; 165: 181-9.

20 Rasmussen HS, Videbaek R, Melchior T, Aurup P, Cintin C, Pedersen NT. Myocardial contractility and performance capacity after magnesium infusions in young healthy persons: a double-blind, placebo-con- 
trolled, cross-over study. Clin Cardiol 1988; 11 : 541-5.

21 Altura BM, Altura BT. Influence of magnesium on drug-induced contractions and ion content of rabbit aorta. Am J Physiol 1971; 220: 938-44.

22 Altura BM, Turlapaty PDMV. Withdrawal of magnesium enhances coronary arterial spasms produced by vasoactive agents. Br J Pharmacol 1982; 77: 649-59

23 Goto K, Yasue H, Okumura K, et al. Magnesium deficiency detected by intravenous loading test in variant angina pectoris. Am J Cardiol 1990; 65: 709-12.

24 Teragawa $H$, Kato $M$, Yamagata $T$, Matsuura $H$, Kajiyama $G$. The preventive effect of magnesium on coronary spasm in patients with vasospastic angina. Chest 2000; 118: 1690-5.

25 Akazawa S, Shimizu R, Nakaigawa $\Upsilon$, Ishii R, Ikeno $S$, Yamato $R$. Effects of magnesium sulphate on atrioventricular conduction times and surface electrocardiogram in dogs anaesthetized with sevoflurane. Br J Anaesth 1997; 78: 75-80.

26 Vigorito C, Giordano A, Ferraro P, et al. Hemodynamic effects of magnesium sulfate on the normal human heart. Am J Cardiol 1991; 67: 1435-7.

27 Delhumeau A, Granry JC, Cottineau C, Bukowski JG, Corbean JJ, Morean X. Comparative vascular effects of magnesium sulphate and nicardipine during cardiopulmonary bypass (French). Ann Fr Anesth Réanim 1995; 14: 149-53.

28 Krendel DA. Hypermagnesemia and neuromuscular transmission. Semin Neurol 1990; 10: 42-5.

29 Mordes JP, Wacker WE. Excess magnesium. Pharmacol Rev 1977; 29: 273-300.

30 Frakes MA, Richardson LE. Magnesium sulfate therapy in certain emergency conditions. Am J Emerg Med 1997; 15: 182-7.

31 Steer CM, Petrie RH. A comparison of magnesium sulfate and alcohol for the prevention of premature labor. Am J Obstet Gynecol 1977; 129: 1-4.

32 Terrone DA, Rinehart BK, Kimmel ES, May WL, Larmon JE, Morrison JC. A prospective, randomized, controlled trial of high and low maintenance doses of magnesium sulfate for acute tocolysis. Am J Obstet Gynecol 2000; 182: 1477-82.

33 Crowther C. Magnesium sulphate versus diazepam in the management of eclampsia: a randomized controlled trial. Br J Obstet Gynaecol 1990; 97: 110-7.

34 Morisaki H, Yamamoto S, Morita $\Upsilon$, Kotake $\Upsilon$, Ochiai $R$, Takeda J. Hypermagnesemia-induced cardiopulmonary arrest before induction of anesthesia for emergency cesarean section. J Clin Anesth 2000; 12: 224-6.

35 Walker JJ. Pre-eclampsia. Lancet 2000; 356: 1260-5.

36 The Magpie Trial Collaboration Group. Do women with pre-eclampsia, and their babies, benefit from magnesium sulphate? The Magpie Trial: a randomised placebo-controlled trial. Lancet 2002; 359: 187-90.

37 Arnold A, Tovey J, Mangat P, Penny W, Jacobs $S$. Magnesium deficiency in critically ill patients. Anaesthesia 1995; 50: 203-5.

38 Wong ET, Rude RK, Singer FR, Shaw ST Jr. A high prevalence of hypomagnesemia and hypermagnesemia in hospitalized patients. Am J Clin Pathol 1983; 79: 348-52.

39 Rubeiz GJ, Thill-Baharozian M, Hardie D, Carlson $R W$. Association of hypomagnesemia and mortality in acutely ill medical patients. Crit Care Med 1993; 21 : 203-9.

40 Whang R, Ryder $K W$. Frequency of hypomagnesemia and hypermagnesemia. Requested vs routine. JAMA 1990; 263: 3063-4.

41 Chernow B, Bamberger S, Stoiko $M$, et al. Hypomagnesemia in patients in postoperative intensive care. Chest 1989; 95: 391-7.

42 Ryzen E, Wagers PW, Singer FR, Rude RK. Magnesium deficiency in a medical ICU population. Crit Care Med 1985; 13: 19-21.

43 England MR, Gordon G, Salem M, Chernow $B$. Magnesium administration and dysrhythmias after cardiac surgery. A placebo-controlled, double-blind, randomized trial. JAMA 1992; 268: 2395-402.

44 Whang R, Whang DD, Ryan MP. Refractory potassium repletion. A consequence of magnesium deficiency. Arch Intern Med 1992; 152: 40-5.

45 Fung MC, Weintraub M, Bowen DL. Hypermagnesemia. Elderly over-the-counter drug users at risk. Arch Fam Med 1995; 4: 718-23.

46 James MFM, Beer RE, Esser JD. Intravenous magnesium sulfate inhibits catecholamine release associated with tracheal intubation. Anesth Analg 1989; 68: 772-6.

47 Puri GD, Marudhachalam KS, Chari P, Suri RK. The effect of magnesium sulphate on hemodynamics and its efficacy in attenuating the response to endotracheal intubation in patients with coronary artery disease. Anesth Analg 1998; 87: 808-11.

48 rap LC, Ho RT, Jawan B, Lee JH. Effects of magnesium sulfate pretreatment on succinylcholine-facilitated tracheal intubation. Acta Anaesthesiol Sin 1994; 32: 45-50.

49 Ashton WB, James MFM, Janicki P, Uys PC. Attenuation of the pressor response to tracheal intubation by magnesium sulphate with and without alfentanil in hypertensive proteinuric patients undergoing caesarean section. Br J Anaesth 1991; 67: 741-7.

50 James MFM. Use of magnesium sulphate in the 
anaesthetic management of phaeochromocytoma: a review of 17 anaesthetics. Br J Anaesth 1989; 62: 616-23.

51 Drolet P, Girard M. The use of magnesium sulfate during surgery of pheochromocytoma: apropos of 2 cases (French). Can J Anaesth 1993; 40: 521-5.

52 Lim KS, Low TC, Ng BK, Rajasoorya C. A case report of the use of magnesium sulphate during anaesthesia in a patient who had adrenalectomy for phaeochromocytoma. Ann Acad Med Singapore 2000; 29: 518-20.

53 Pitt-Miller P, Primus E. Use of magnesium sulphate as adjunctive therapy for resection of phaeochromocytoma. West Indian Med J 2000; 49: 73-5.

54 James MFM, Huddle KRL, Owen AD, van der Veen $B W$. Use of magnesium sulphate in the anaesthetic management of phaeochromocytoma in pregnancy. Can J Anaesth 1988; 35: 178-82.

55 Zaman AG, Alamgir F, Richens T, Williams R, Rothman MT, Mills PG. The role of signal averaged $\mathrm{P}$ wave duration and serum magnesium as a combined predictor of atrial fibrillation after elective coronary artery bypass surgery. Heart 1997; 77: 527-31.

56 Yeatman $M$, Caputo $M$, Narayan $P$, et al. Magnesium-supplemented warm blood cardioplegia in patients undergoing coronary artery revascularization. Ann Thorac Surg 2002; 73: 112-8.

57 Toraman F, Karabulut EH, Alhan HC, Dagdelen S, Tarcan $S$. Magnesium infusion dramatically decreases the incidence of atrial fibrillation after coronary artery bypass grafting. Ann Thorac Surg 2001; 72: 1256-61.

58 Nastou H, Sarros G, Nastos A, Sarrou V, Anastassopoulou J. Prophylactic effects of intravenous magnesium on hypertensive emergencies after cataract surgery. A new contribution to the pharmacological use of magnesium in anaesthesiology. Magnes Res 1995; 8: 271-6.

59 Bert AA, Reinert SE, Singh AK. A B-blocker, not magnesium, is effective prophylaxis for atrial tachyarrhythmias after coronary artery bypass graft surgery. J Cardiothorac Vasc Anesth 2001; 15: 204-9.

60 Dorman BH, Sade RM, Burnette JS, et al. Magnesium supplementation in the prevention of arrhythmias in pediatric patients undergoing surgery for congenital heart defects. Am Heart J 2000; 139: 522-8.

61 Keren A, Tzivoni D. Torsades de pointes: prevention and therapy. Cardiovasc Drugs Ther 1991; 5: 509-14.

62 Moran JL, Gallagher J, Peake SL, Cunningham DN, Salagaras $M$, Leppard P. Parenteral magnesium sulphate versus amiodarone in the therapy of atrial tachyarrhythmias. a prospective, randomized study. Crit
Care Med 1995; 23: 1816-24.

63 Rudnicki M, Frolich A, Rasmussen WF, McNair P. The effect of magnesium on maternal blood pressure in pregnancy-induced hypertension. Acta Obstet Gynecol Scand 1991; 70: 445-50.

64 Rudnicki M, Frolich A, Pilsgaard K, et al. Comparison of magnesium and methyldopa for the control of blood pressure in pregnancies complicated with hypertension. Gynecol Obstet Invest 2000; 49: 231-5.

65 Vincent RD Jr, Chestnut DH, Sipes SL, Weiner CP, DeBruyn CS, Bleuer SA. Magnesium sulfate decreases maternal blood pressure but not uterine blood flow during epidural anesthesia in gravid ewes.

Anesthesiology 1991; 74: 77-82.

66 Lu JF, Nightingale CH. Magnesium sulfate in eclampsia and pre-eclampsia. Clin Pharmacokinet 2000; 38: 305-14.

67 The Eclampsia Trial Collaborative Group. Which anticonvulsant for women with eclampsia? Evidence from the Collaborative Eclampsia Trial. Lancet 1995; 345: 1455-63.

68 Belfort MA, Moise KJ Jr. Effect of magnesium sulfate on maternal brain blood flow in preeclampsia: a randomized, placebo-controlled study. Am J Obstet Gynecol 1992; 167: 661-6.

69 Coetzee EJ, Dommisse J, Anthony J. A randomised controlled trial of intravenous magnesium sulphate versus placebo in the management of women with severe pre-eclampsia. Br J Obstet Gynaecol 1998; 105: 300-3.

70 Chen FP, Chang SD, Chu KK. Expectant management in severe preeclampsia: does magnesium sulphate prevent the development of eclampsia? Acta Obstet Gynecol Scand 1995; 74: 181-5.

71 Lucas MJ, Leveno KJ, Cunningham FG. A comparison of magnesium sulfate with phenytoin for the prevention of eclampsia. N Engl J Med 1995; 333: 201-5.

72 Friedman SA, Lim KH, Baker CA, Repke JT. Phenytoin versus magnesium sulphate in preeclampsia: a pilot study. Am J Perinatol 1993; 10: 233-8.

73 Appleton MP, Kuebl TJ, Raebel MA, Adams HR, Knight $A B$, Gold WR. Magnesium sulfate versus phenytoin for seizure prophylaxis in pregnancyinduced hypertension. Am J Obstet Gynecol 1991; 165: 907-13

74 Chien PFW, Khan KS, Arnott N. Magnesium sulphate in the treatment of eclampsia and pre-eclampsia: an overview of the evidence from randomised trials. Br J Obstet Gynaecol 1996; 103: 1085-91.

75 Dommisse J. Phenytoin sodium and magnesium sulphate in the management of eclampsia. Br J Obstet Gynaecol 1990; 97: 104-9. 
76 Nelson KB, Grether JK. Can magnesium sulfate reduce the risk of cerebral palsy in very low birthweight infants? Pediatrics 1995; 95: 263-9.

77 FineSmith RB, Roche K, Yellin PB, et al. Effect of magnesium sulfate on the development of cystic periventricular leukomalacia in preterm infants. Am J Perinatol 1997; 14: 303-7.

78 Canterino JC, Verma UL, Visintainer PF, Figueroa R, Klein SA, Tejani NA. Maternal magnesium sulfate and the development of neonatal periventricular leucomalacia and intraventricular hemorrhage. Obstet Gynecol 1999; 93: 396-402.

79 Grether JK, Hoogstrate J, Walsh-Greene E, Nelson KB. Magnesium sulfate for tocolysis and risk of spastic cerebral palsy in premature children born to women without preeclampsia. Am J Obstet Gynecol 2000; 183: 717-25.

80 Paneth N, Jetton J, Pinto-Martin J, Susser M. Magnesium sulfate in labor and risk of neonatal brain lesions and cerebral palsy in low birth weight infants. The Neonatal Brain Hemorrhage Study Analysis Group. Pediatrics 1997; 99: el.

81 Mittendorf R, Covert R, Boman J, Khoshnood B, Lee $K S$, Siegler $M$. Is tocolytic magnesium sulphate associated with increased total paediatric mortality? (Letter). Lancet 1997; 350: 1517-8.

82 Mittendorf R, Covert R, Elin R, Pryde PG, Khosnood $B$, Lee KS. Umbilical cord serum ionized magnesium level and total pediatric mortality. Obstet Gynecol 2001; 98: 75-8.

83 Ghoneim MM, Long JP. The interaction between magnesium and other neuromuscular blocking agents. Anesthesiology 1970; 32: 23-7.

84 Schulz-Stubner S, Wettmann G, Reyle-Hahn SM, Rossaint $R$. Magnesium as part of balanced general anaesthesia with propofol, remifentanil and mivacurium: a double-blind, randomized prospective study in 50 patients. Eur J Anaesthesiol 2001; 18: 723-9.

85 Thompson SW, Moscicki JC, DiFazio CA. The anesthetic contribution of magnesium sulfate and ritodrine hydrochloride in rats. Anesth Analg 1988; 67: 31-4.

86 Hollmann MW, Liu HT, Hoenemann CW, Liu WH, Durieux ME. Modulation of NMDA receptor function by ketamine and magnesium. Part II: interactions with volatile anesthetics. Anesth Analg 2001; 92: 1182-91.

87 Orser B, Smith D, Henderson S, Gelb A. Magnesium deficiency increases ketamine sensitivity in rats. Can J Anaesth 1997; 44: 883-90.

88 Liu HT, Hollmann MW, Liu WH, Hoenemann CW, Durieux ME. Modulation of NMDA receptor function by ketamine and magnesium: Part I. Anesth
Analg 2001; 92: 1173-81.

89 Wilder-Smith OHG, Arendt-Nielsen L, Gäumann D, Tassonyi E, Rifat KR. Sensory changes and pain after abdominal hysterectomy: a comparison of anesthetic supplementation with fentanyl versus magnesium or ketamine. Anesth Analg 1998; 86: 95-101.

90 Zarauza R, Sáez-Fernández AN, Iribarren MJ, et al. A comparative study with oral nifedipine, intravenous nimodipine, and magnesium sulfate in postoperative analgesia. Anesth Analg 2000; 91: 938-43.

91 Wilder-Smith CH, Knöpfli R, Wilder-Smith OHG. Perioperative magnesium infusion and postoperative pain. Acta Anaesthesiol Scand 1997; 41: 1023-7.

92 Kroin JS, McCarthy RJ, Von Roenn N, Schwab B, Tuman KJ, Ivankovich AD. Magnesium sulfate potentiates morphine antinociception at the spinal level. Anesth Analg 2000; 90: 913-7.

93 Horner SM. Efficacy of intravenous magnesium in acute myocardial infarction in reducing arrhythmias and mortality. Meta-analysis of magnesium in acute myocardial infarction. Circulation 1992; 86: 774-9.

94 Teo KK, Yusuf S, Collins R, Held PH, Peto R. Effects of intravenous magnesium in suspected acute myocardial infarction: overview of randomised trials. BMJ 1991; 303: 1499-503.

95 Gyamlani $G$, Parikh C, Kulkarni AG. Benefits of magnesium in acute myocardial infarction: timing is crucial. Am Heart J 2000; 139: e2.

96 Woods KL, Flether S, Roffe C, Haider $\Upsilon$. Intravenous magnesium sulphate in suspected acute myocardial infarction: results of the second Leicester Intravenous Magnesium Intervention Trial (LIMIT-2). Lancet 1992; 339: 1553-8.

97 Woods KL, Flethcher S. Long-term outcome after intravenous magnesium sulphate in suspected acute myocardial infarction: the second Leicester Intravenous Magnesium Intervention Trial (LIMIT2). Lancet $1994 ; 343: 816-9$.

98 ISIS-4 Fouth International Study of Infarct Survival Collaborative Group. ISIS-4: a randomised factorial trial assessing early oral captopril, oral mononitrate, and intravenous magnesium sulphate in 58050 patients with suspected acute myocardial infarction. Lancet 1995; 345: 669-85.

99 Anonymous. Rationale and design of the magnesium in coronaries (MAGIC) study: a clinical trial to reevaluate the efficacy of early administration of magnesium in acute myocardial infarction. The MAGIC Steering Committee. Am Heart J 2000; 139: 10-4.

100 The Magnesium in Coronaries (MAGIC) Trial Investigators. Early administration of intravenous magnesium to high-risk patients with acute myocardial infarction in the magnesium in Coronaries 
(MAGIC) Trial: a randomised controlled trial. Lancet 2002; 360: 1189-96.

101 Fatovich DM, Prentice DA, Dobb GJ. Magnesium in cardiac arrest (the magic trial). Resuscitation 1997; 35: 237-41.

102 Thel MC, Armstrong AL, McNulty SE, Califf RM, $O^{\prime}$ Connor CM. Randomised trial of magnesium in inhospital cardiac arrest. Duke Internal Medicine Housestaff. Lancet 1997; 350: 1272-6.

103 Rowe BH, Bretzlaff JA, Bourdon C, Bota GW, Camargo $C A$. Intravenous magnesium sulfate treatment for acute asthma in the emergency department: a systematic review of the literature. Ann Emerg Med 2000; 36: 181-90.

104 Alter HJ, Koepsell TD, Hilty WM. Intravenous magnesium as an adjuvant in acute bronchospasm: a meta-analysis. Ann Emerg Med 2000; 36: 191-7.

105 Rodrigo G, Rodrigo C, Burschtin O. Efficacy of magnesium sulfate in acute adult asthma: a meta-analysis of randomized trials. Am J Emerg Med 2000; 18 : 216-21.

106 Devi PR, Kumar L, Singhi SC, Prasad R, Singh M. Intravenous magnesium sulfate in acute severe asthma not responding to conventional therapy. Indian Pediatr 1997; 34: 389-97.

107 Ciarallo L, Sauer AH, Shannon MW. Intravenous magnesium therapy for moderate to severe pediatric asthma: results of a randomized, placebo-controlled trial. J Pediatr 1996; 129: 809-14.

108 Mangat HS, D'Souza GA, Jacob MS. Nebulized magnesium sulphate versus nebulized salbutamol in acute bronchial asthma: a clinical trial. Eur Respir J 1998; 12: 341-4.

109 Skobeloff EM, Spivey WH, McNamara RM, Greenspon $L$. Intravenous magnesium sulfate for the treatment of acute asthma in the emergency department. JAMA 1989; 262: 1210-3.

110 Bloch H, Silverman R, Mancherje N, Grant S, Jagminas L, Scharf SM. Intravenous magnesium sulfate as an adjunct in the treatment of acute asthma. Chest 1995; 107: 1576-81.

111 Ciarallo L, Brousseau D, Reinert S. Higher-dose intravenous magnesium therapy for children with moderate to severe acute asthma. Arch Pediatr Adolesc Med 2000; 154: 979-83.

112 Boulet LP, Becker A, Bérubé D, Beveridge R, Ernst P. Canadian Asthma Consensus Report, 1999. Canadian Asthma Consensus Group. CMAJ 1999; 161(11 Suppl): S1-S61.

113 Attygalle D, Rodrigo N. Magnesium as first line therapy in the management of tetanus: a prospective study of 40 patients. Anaesthesia 2002; 57: 778-817.

114 Lozo E, Riecke K, Schwabe R, Vormann J, Stahlmann
$R$. Synergistic effect of ofloxacin and magnesium deficiency on joint cartilage in immature rats. Antimicrob Agents Chemother 2002; 46: 1755-9.

115 Grolleau F, Gamelin L, Boisdron-Celle M, Lapied B, Pelhate $M$, Gamelin E. A possible explanation for a neurotoxic effect of the anticancer agent oxaliplatin on neuronal voltage-gated sodium channels. J Neurophysiol 2001; 85: 2293-7. 